\title{
ANALYSIS OF PRICING AND MERCHANDISING EFFECT TO CUSTOMER SATISFACTION AND IT'S AFFECTED TO CUSTOMER LOYALTY IN PURI BATAM MINIMARKET
}

\author{
Shinta Wahyu Hati dan Nurlidiya Parlewenti \\ Department of Applied Business Administration, Politeknik Negeri Batam \\ Email : shinta@polibatam.ac.id,nurlidyapalawenti@yahoo.co.id
}

\begin{abstract}
The purpose of this study was to determine the effect of price variable and merchandising variable on customer satisfaction variabel, to determine the effect of direct price variable and merchandising variable on customer loyalty, and to determine the effect of direct price and merchandising variable on customer loyalty variable with satisfaction as intervening variable. This kind of research is explanatory research with quantitative approach. Research sample is 161 customer of Minimarket Puri Batam. This research use analysis method Path Analysis. The results showed significant effect on the price variable Customer Satisfaction with value 0.474, and merchandising significantly contributing to customer satisfaction with value 0.413. Price significantly contributing to customer loyalty with value 0.260, merchandising significantly contributing to customer loyalty with value 0.295. And customer satisfaction significantly contributing to customer loyalty with value 0.263. The result of this study are price, merchandising, and satisfaction have a significant influence on customer loyalty.
\end{abstract}

Keywords : Loyalty, merchandising, price, satisfaction

\section{ANALISIS PENGARUH HARGA DAN MERCHANDISING TERHADAP KEPUASAN PELANGGAN DAN DAMPAKNYA PADA LOYALITAS PELANGGAN DI MINIMARKET PURI BATAM}

\begin{abstract}
ABSTRAK
Tujuan penelitian ini adalah untuk mengetahui pengaruh harga dan merchandising terhadap kepuasan pelanggan, pengaruh harga dan merchandising terhadap loyalitas pelanggan dengan kepuasan pelanggan sebagai variabel intervening. Jenis penelitian ini adalah penelitian eksplanatori dengan pendekatan kuantitatif. Sampel dalam penelitian ini sebanyak 161 orang pelanggan Minimarket Puri. Teknik analisis data yang digunakan adalah menggunakan analisis jalur. Hasil penelitian menunjukkan variabel harga berpengaruh signifikan terhadap kepuasan pelanggan sebesar 0.474 dan variabel merchandising berpengaruh signifikan terhadap kepuasan pelanggan sebesar 0.413. Variabel harga berpengaruh signifikan terhadap loyalitas pelanggan sebesar 0.260 . Merchandising mempunyai pengaruh yang signifikan terhadap loyalitas pelanggan sebesar 0.295. Variabel kepuasan pelanggan mempunyai pengaruh signifikan sebesar 0.263 terhadap loyalitas pelanggan. Kesimpulan dalam penelitian ini adalah harga, merchandising dan kepuasan pelanggan memiliki pengaruh terhadap loyalitas pelanggan.
\end{abstract}

Kata kunci: Harga, loyalitas, merchandising, kepuasan 


\section{PENDAHULUAN}

Perekonomian di era modern kini mengalami mengalami persaingan yang semakin meningkat, apalagi pasar modern terus-menerus bertambah dan seiring dengan berjalannya waktu memperluas wilayahnya dengan menawarkan produk, harga, pelayanan dan kenyamanan yang baik kepada masyarakat. Keberadaan pasar modern seperti Alfamart dan Indomaret dapat menjadi sebuah ancaman bagi peritel-peritel kecil yang belum mempunyai nama di masyarakat. Persaingan yang cukup pesat ini harus diimbangi dengan pengetahuan pengusaha ritel untuk dapat beradaptasi dengan melakukan perubahan meningkatkan strategi dalam berbisnis ritel untuk dapat mempertahankan bisnis ritelnya.

Melihat jumlah penduduk di Kota Batam yang semakin meningkat, dan mengingat penduduknya yang semakin konsumtif penting untuk para pengusahan ritel dapat bersaing dan meningkatkan bisnisnya. Untuk dapat meningkatkan bisnis ritelnya para pengusaha ritel harus memperhatikan bauran-bauran ritel seperti harga, merchandising, lokasi, atmosfir toko dan pelayanan. Menurut Justin dalam Santoso (2012), bauran pemasaran ritel (retail marketing mix) adalah variabel keputusan pengecer yang digunakan untuk memenuhi kebutuhan pelanggan dan mempengaruhi mereka dalam keputusan pembelian dan dengan demikian mempengaruhi komitmen pelanggan dengan cara menciptakan kepuasan. Akan tetapi dalam prakteknya, seringkali ditemui suatu dilema yang dihadapi oleh para pemasar, yaitu adalah bagaimana cara mengembangkan bauran pemasaran ritel yang tidak hanya efektif memenuhi target pasar, tetapi juga membangun komitmen dan loyalitas pelanggan.

Minimarket Puri merupakan salah satu perusahaan ritel yang berskala Usaha Kecil Menengan (UKM) yang ada Kota Batam dan telah 5 tahun beroperasi memenuhi kebutuhan warga sekitarnya. Kebutuhan warga sekitar untuk berbelanja adalah wanita, wanita di lingkungan sekitar sering berbelanja kebutuhan pokok dan juga kebutuhan lainnya.

Wanita dianggap memiliki peran dalam menentukan keputusan pola belanja di keluarganya, terutama memegang keputusan kunci untuk berbelanja barang/produk keluarga dan individu perempuan itu sendiri. Menurut Barleta (2004) Wanita adalah pengambil keputusan utama untuk barang-barang konsumen di 85\% rumah tangga. Wanita menetapkan keputusan pembelian produk barang/jasa dengan cara yang berbeda dibanding laki-laki. Keduanya berkomunikasi dengan cara yang berbeda dan mereka tidak membeli dengan alasan yang sama. Wanita hanya menekankan bahwa ingin langsung bertransaksi langsung.

Bisa dikatakan bahwa perusahaan harus mempertimbangkan dan memikirkan strategi pemasaran untuk setiap pembeli potensial wanita sebagai individu yang fokus pada kebutuhan dirinya dan keluarganya.

Tidak mudah untuk Minimarket Puri dalam melakukan pengelolahan bauran ritel dan mampu bersaing, terutama dalam menetapkan harga dan melengkapi barang dagangan yang dibutuhkan pelanggan. mengingat banyaknya usaha ritel juga yang ada disekitar Minimarket Puri.

Adanya banyak tawaran yang bisa diberikan kepada konsumen pada akhirnya membuat konsumen bebas untuk memilih harga yang terbaik dari semua pilihan yang ada. harga adalah faktor pisitioning kunci dan harus diputuskan dalam hubungannya dengan pasar sasaran, bauran pilihan produk, jasa dan persaingan (Kotler \& Keller, 2008:151). Pengelolaan barang dagangan (merchandising) adalah proses penanganan kreatif dalam upaya untuk mempresentasikan daya tarik penjualan ritel (Utami, 2010:193).

Berdasarkan latar belakang yang telah diuraikan di atas, maka dilakukan penelitian dengan judul "Pengaruh Harga dan Merchandising terhadap Kepuasan Pelanggan 
dan Dampaknya Terhadap Loyalitas Pelanggan Di Minimarket Puri Batam"

\section{TINJAUAN PUSTAKA}

\section{Harga}

Menurut Supranto (2007:12), harga ialah sejumlah uang seseorang harus membayar untuk mendapatkan hak menggunakan produk. Seseorang bisa membeli pemilikan suatu produk, banyak produk, hak penggunaan terbatas. Menurut Tjiptono (2012: 315), istilah harga bisa diartikan sebagai jumlah uang (satuan moneter) atau aspek lain (non-moneter) yang mengandung utilitas/kegunaan tertentu yang diperlukan untuk mendapatkan sebuah produk. Retail pricing adalah value yang dirasakan oleh konsumen dan rasio yang diterima oleh pelanggan (Levy \& Weith dalam Wahono, 2013).

\section{Merchandising}

Merchandising adalah kegiatan pengadaan barang-barang yang sesuai dengan bisnis yang dijalani toko untuk disediakan dengan jumlah, waktu, dan harga yang sesuai untuk mencapai sasaran toko atau perusahaan ritel (Ma'ruf dalam Sopiah, 2008:141). "Assorment is the number of different item in a merchandise category." yang berarti assortment adalah jumlah item yang berbeda dalam kategori barang dagangan (Levy \& Weith dalam Wahono, 2013).

Semua ritel menghadapi masalah mengenai strategi yang paling dasar yaitu jenis format ritel untuk memperoleh keuntungan yang kompetitif dan dapat menopang keseluruhan rencana kerja ritel tersebut. Komponen yang paling kritis dalam keputusan ini adalah menentukan keberagaman barang dagangan yang akan ditawarkan pada pelanggan untuk diinventariskan dalam inventaris barang dagangan dan keterbatasan luas yang tersedia dalam toko.

\section{Kepuasan Pelanggan}

Menurut Zeithaml dan Bitner dalam Etta (2013:180-181), kepuasan konsumen merupakan "customer's evaluation of a product or service in terms of whether that product or service has met their needs and expectation." Konsumen yang merasa puas pada produk/jasa yang dibeli dan digunakannya akan kembali menggunakan jasa/produk yang ditawarkan. Kepuasan konsumen adalah perasaan senang atau kecewa yang muncul setelah membandingkan persepsi atau kesan dengan kinerja suatu produk dan harapan-harapannya (Kotler dalam Mamang, 2013:181).

Kepuasan konsumen diartikan sebagai suatu keadaan di mana harapan konsumen terhadap suatu produk sesuai dengan kenyataan yang diterima oleh konsumen. Jika produk tersebut jauh dibawah harapan, konsumen akan kecewa. Sebaliknya, jika produk tersebut memenuhi harapan, konsumen akan puas. Harapan konsumen dapat diketahui dari pengalaman mereka sendiri saat menggunakan produk tersebut, informasi dari orang lain, dan informasi yang diperoleh dari iklan atau promosi yang lain (Mamang, 2013:181).

\section{Loyalitas Pelanggan}

Loyalitas pelanggan adalah komitmen pelanggan bertahan secara mendalam untuk berlangganan kembali atau melakukan pembelian ulang produk atau jasa terpilih secara konsisten di masa yang akan datang, meskipun pengaruh situasi dan usaha-usaha pemasaran mempunyai potensi untuk menyebabkan perubahan perilaku (Hurriyati dalam Mamang, 2013).

Konsumen yang loyal merupakan aset penting bagi perusahaan. Hal ini dapat dilihat dari karakteristik yang dimilikinya. Griffin dalam Etta (2013), menyatakan bahwa konsumen yang loyal memiliki karakteristik sebagai berikut:

1. Melakukan pembelian secara teratur (makes reguler repeat purchase) 
2. Melakukan pembelian di semua lini produk atau jasa (purchases across product and service lines)

3. Merekomendasikan produk lain (refers other)

4. Menunjukkan kekebalan dari daya tarik produk sejenis dari pesaing (demonstrates on immunity to the full of the competition).

\section{METODE PENELITIAN}

Rancangan penelitian ini menggunakan pendekatan eksplanatori (explanatory research), merupakan penelitian yang menjelaskan hubungan kausal antara variabel penelitian dengan pengujian hipotesis. Objek yang akan diteliti adalah penetapan harga dan pengelolaan barang dagangan (merchandising) Minimarket Puri di Puri Legenda Batam.

Populasi adalah kumpulan unit yang akan diteliti ciri-ciri (karakteristik) nya, dan apabila populasinya terlalu luas, maka peneliti harus mengambil sampel (bagian dari populasi) untuk diteliti (Ma'ruf, 2015). Populasi penelitian ini adalah wanita yang pernah berbelanja di Minimarket Puri Batam. Teknik pengambilan sampel penelitian adalah purposive sampling.
Menurut Jogiyanto (2007), pengambilan sampel bertujuan (purposive sampling) dilakukan dengan mengambil sampel dari populasi berdasarkan suatu kriteria tertentu.

Jumlah pelanggan wanita yang berbelanja kurang lebih sebanyak 270 jiwa perhari, dan dengan taraf kesalahan 5\%

Penentuan sampel dengan menggunakan rumus Slovin:

$$
n=\frac{N}{1+N(e)^{2}}
$$

n : Ukuran sampel / jumlah responden

$\mathrm{N}$ : Ukuran populasi

e.: Toleransi ketidaktelitian dalam persen $(\%)$

$$
\begin{aligned}
& \mathrm{n}=\frac{2}{1+2(0.0)^{2}} \\
& \mathrm{n}=\frac{2}{1+0.6} \\
& \mathrm{n}=161.19
\end{aligned}
$$

Jadi sampel yang diambil adalah sebanyak 161 jiwa. Teknik pengumpulan data menggunakan kuesioner. Cara pengumpulan data dengan menyebarkan daftar pertanyaan kepada responden, dengan harapan mereka akan memberikan respon atas daftar pertanyaan

\begin{tabular}{|c|c|c|}
\hline Konsep & Variabel & Indikator \\
\hline $\begin{array}{l}\text { Retail pricing adalah value yang dirasakan } \\
\text { oleh konsumen dan rasio yang diterima oleh } \\
\text { pelanggan. (Levy \& Weith dalam Wahono } \\
\text { 2013). Dan Strategi kebijakan penetapan } \\
\text { harga merupakan suatu masalah jika } \\
\text { perusahaan akan menetapkan harga pertama } \\
\text { kalinya, karena penetapan harga akan } \\
\text { mempengaruhi pendapatan total dan biaya. } \\
\text { Harga merupakan faktor utama penentuan } \\
\text { posisi dan harus diputuskan sesuai dengan } \\
\text { pasar sasaran, bauran ragam, produk, dan } \\
\text { pelayanan, serta persaingan Kotler dan } \\
\text { Amstrong dalam Poster (2008). }\end{array}$ & $\begin{array}{l}\text { Variabel Eksogen 1: } \\
\text { Harga (X1) }\end{array}$ & $\begin{array}{l}\text { 1. Kestabilan harga } \\
\text { 2. Kesesuaian harga pasar } \\
\text { 3. Harga bersaing } \\
\text { 4. Harga promosi } \\
\text { 5. Per item price } \\
\text { 6. Communication price } \\
\text { 7. Know value item price }\end{array}$ \\
\hline $\begin{array}{l}\text { "Assortment is the number of different items } \\
\text { in a merchandise category." Yang berarti } \\
\text { assortment adalah jumlah item yang berbeda } \\
\text { dalam kategori barang dagangan (Levy \& } \\
\text { Weith dalam Wahono 2013). Semua ritel }\end{array}$ & $\begin{array}{l}\text { Variabel Eksogen 2: } \\
\text { Merchandising } \\
\text { (X2) }\end{array}$ & 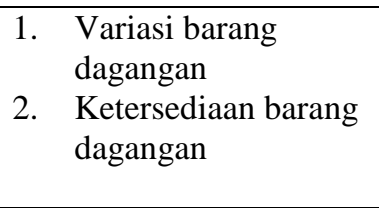 \\
\hline
\end{tabular}
tersebut (Ma'ruf, 2015:248).

\section{Operasionalisasi Variabel Penelitian}

Tabel 1 Operasional Variabel Penelitian 


\begin{tabular}{|c|c|c|}
\hline $\begin{array}{l}\text { menghadapi masalah mengenai strategi yang } \\
\text { paling dasar yaitu jenis format ritel untuk } \\
\text { memperoleh keuntungan yang kompetitif } \\
\text { dan dapat menopang keseluruhan rencana } \\
\text { kerja ritel tersebut. Komponen yang paling } \\
\text { kritis dalam keputusan ini adalah } \\
\text { menentukan keberagaman barang dagangan } \\
\text { yang akan ditawarkan pada pelanggan. } \\
\text { Untuk diinvestasikan dalam inventaris } \\
\text { barang dagangan dan keterbatasan luas yang } \\
\text { tersedia dalam toko. }\end{array}$ & & $\begin{array}{l}\text { 3. Keberagaman barang } \\
\text { dagangan } \\
\text { 4. Ukuran barang } \\
\text { dagangan bervariasi }\end{array}$ \\
\hline $\begin{array}{l}\text { Kepuasan konsumen adalah perasaan senang } \\
\text { atau kecewa yang muncul setelah } \\
\text { membandingkan persepsi atau kesan dengan } \\
\text { kinerja suatu produk dan harapan- } \\
\text { harapannya Kotler dalam Mamang (2013: } \\
\text { 181). }\end{array}$ & 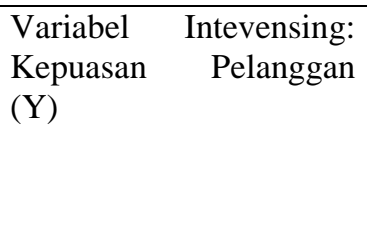 & $\begin{array}{l}\text { 1. Sesuai harapan } \\
\text { pelanggan } \\
\text { 2. Melampaui harapan } \\
\text { pelanggan }\end{array}$ \\
\hline $\begin{array}{l}\text { Loyalitas pelanggan adalah komitmen } \\
\text { pelanggan bertahan secara mendalam untuk } \\
\text { berlangganan kembali atau melakukan } \\
\text { pembelian ulang produk atau jasa terpilih } \\
\text { secara konsisten di masa yang akan datang, } \\
\text { meskipun pengaruh situasi dan usaha-usaha } \\
\text { pemasaran mempunyai potensi untuk } \\
\text { menyebabkan perubahan perilaku Hurriyati } \\
\text { dalam Mamang (2013). Griffin dalam Foster } \\
\text { (2008) yang menyatakan bahwa "sukses } \\
\text { tidaknya suatu perusahaan dalam menciptakan } \\
\text { pelanggan yang loyal sangat bergantung pada } \\
\text { kemampuan perusahaan dalam menciptakan } \\
\text { nilai, dan secara terus-menerus berupaya } \\
\text { untuk memperbaiki". }\end{array}$ & $\begin{array}{l}\text { Variabel Endogen: } \\
\text { Loyalitas Pelanggan }(\mathrm{Z})\end{array}$ & $\begin{array}{l}\text { 1. Pelanggan melakukan } \\
\text { pembelian ulang } \\
\text { 2. Pelanggan melakukan } \\
\text { pembelian di semua lini } \\
\text { produk } \\
\text { 3. Pelanggan } \\
\text { merekomendasikan }\end{array}$ \\
\hline
\end{tabular}

\section{Validitas}

Validitas menunjukkan seberapa nyata suatu pengujian mengukur apa yang seharusnya diukur. Validitas berhubungan dengan ketetapan alat ukur untuk malakukan tugasnya mencapai sasarannya (Jogiyanto, 2017). Uji validitas yang akan dilakukan adalah menggunakan metode Pearson's Product Moment, yaitu dengan mengkorelasikan skor butir pada kuesioner dengan skor total nilainya. Apabila $r_{h i}>$ $r_{t}$, artinya terdapat korelasi antara variabel X dengan variabel $\mathrm{Y}$ dan dikatakan valid. Apabila $r_{h i t}<r_{t}$, artinya tidak terdapat korelasi antara variabel $\mathrm{X}$ dengan variabel $\mathrm{Y}$ dan dikatakan tidak valid. Berikut rumus Pearson's Product Momment

$$
r=\frac{N(\Sigma X Y)-(\Sigma X \Sigma Y)}{\left\{n\left(\Sigma X^{2}\right)-(\Sigma X)^{2}\right)\left\{n\left(\Sigma Y^{2}\right)-(\Sigma Y)^{2}\right\}}
$$

Berikut hasil uji validitas dan reliabilitas instrument: 
Tabel 2 Uji Validitas Harga (X1)

\begin{tabular}{|c|c|c|c|c|c|}
\hline Yarisuber & Item Variabel & theturs & rtased & \begin{tabular}{c|c|} 
Touat \\
Signinganai
\end{tabular} & Keicraresan \\
\hline \multirow{17}{*}{$\begin{array}{l}\text { Harga } \\
|x| y \mid\end{array}$} & XI.1.1 Hararakto & $\cos x$ & c.2s02 & ato & Voild \\
\hline & X1.12 Haxulds gaish & 074 & curor & $a a^{\prime}$ & vaid \\
\hline & X12:1 Hargavanta & ors & 0.1301 & $o n$ & valit \\
\hline & 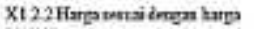 & & & & \\
\hline & paserion & $\operatorname{absa}$ & $0.2 \sin$ & ats & Vaid \\
\hline & 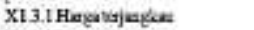 & 0.668 & a.1302 & 0.05 & Void \\
\hline & $\mathrm{X} 13.2$ Herpaloning & 0.625 & 0.2301 & a.06 & Void \\
\hline & X13.3 Hryealutsl mush & $\operatorname{atas}$ & a ssan & $\operatorname{ats}$ & vait \\
\hline & 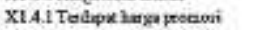 & abt: & 0.2302 & 0.05 & vaid \\
\hline & X1.4.2 Here procosolintinm & acos & 0.2301 & 0.00 & Wait \\
\hline & 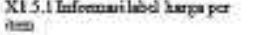 & 0.553 & $6+301$ & 0005 & Vaid \\
\hline & 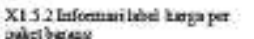 & $0 \leq 0 \%$ & c.240. & & Yaaud \\
\hline & peda & & & & \\
\hline & & 0.545 & 6.302 & 0.05 & void \\
\hline & 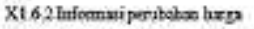 & osos & 0.2801 & 005 & valid \\
\hline & 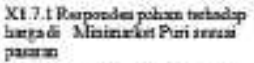 & 0.98 & c.s3os & $O B$ & Vaid \\
\hline & 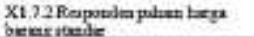 & 0.57 & 62301 & ots & Void \\
\hline
\end{tabular}

Sumber data diolah tahun 2016

Apabila $r_{h u} \quad>r_{t_{1}}$, artinya terdapat korelasi antara variabel $\mathrm{X}$ dengan variabel $\mathrm{Y}$ dan dikatakan valid.

Tabel 3 Uji Validitas Merchandising (X2)

\begin{tabular}{|c|c|c|c|c|c|}
\hline Yarisod & Dor Varibes. & thens & rabdi & 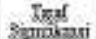 & Kosmurn \\
\hline \multirow{9}{*}{ 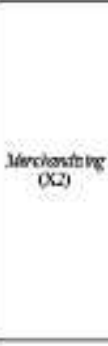 } & $\mathrm{XZ} .11$ Warkbaras kecrias & 0378 & $2+139$ & 000 & Vod \\
\hline & X2.12Exwo brers bersina & 0558 & 6131 & 005 & vad \\
\hline & 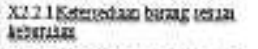 & 20.448 & 01321 & 000 & vad \\
\hline & 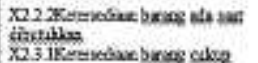 & 0.501 & 0133 & 0.05 & vë̊ \\
\hline & knd & ares & 0.131 & 0.05 & vod \\
\hline & nosadx & 0320 & $019 \mathrm{~m}$ & 006 & Vมีล \\
\hline & 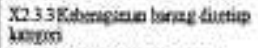 & as 48 & 01301 & 005 & vend \\
\hline & 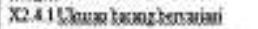 & 0591 & 913 & 0.65 & Vä̀ \\
\hline & 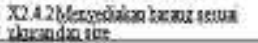 & 0.01 & 0131 & 005 & Veud \\
\hline
\end{tabular}

Sumber data diolah tahun 2016

Apabila $r_{h u ̈}>r_{t_{1}}$, artinya terdapat korelasi antara variabel $\mathrm{X}$ dengan variabel $\mathrm{Y}$ dan dikatakan valid

Tabel 4 Uji Validitas Kepuasan Pelanggan (Y)

\begin{tabular}{|c|c|c|c|c|c|}
\hline Yaxatel & Ees Yaubs & thumg & tabet & $\begin{array}{l}\text { 7anf } \\
\text { Sgritigan: }\end{array}$ & Betesconex: \\
\hline \multirow{4}{*}{ (I) } & \multicolumn{4}{|l|}{ 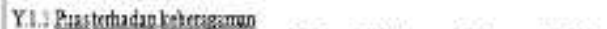 } & Fid \\
\hline & Y.12Bustulusag layg & 0829 & 0.1301 & 805 & Wahl \\
\hline & 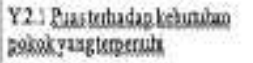 & $0.76 !$ & 0.1901 & 200 & Fald \\
\hline & 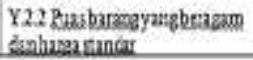 & 0.631 & 0.1201 & 205 & Yhid \\
\hline
\end{tabular}

Sumber data diolah tahun 2016

Apabila $r_{h i} \quad>r_{t_{i}}$, artinya terdapat korelasi antara variabel $\mathrm{X}$ dengan variabel $\mathrm{Y}$ dan dikatakan valid
Tabel 5 Uji Validitas Loyalitas Pelanggan (Z)

\begin{tabular}{|c|c|c|c|c|c|}
\hline Yasiated & 1em Yasile & $=20 \mathrm{~ns}$ & that & $\begin{array}{c}\text { Ieaf } \\
\text { 3initane }\end{array}$ & Recramose \\
\hline \multirow{6}{*}{$\begin{array}{l}\text { Irathes } \\
\text { zedruseut } \\
\text { (A) }\end{array}$} & 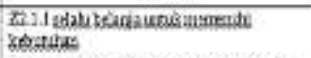 & $60: 3$ & 0.3301 & 605 & $\operatorname{vos}$ \\
\hline & 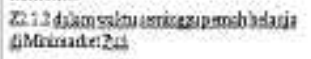 & $s .7 \pm t$ & 0.3301 & 505 & vat \\
\hline & 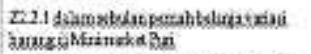 & 2,698 & 0.1301 & 205 & Vis \\
\hline & 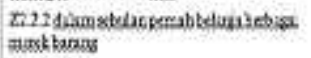 & 2621 & 0.3301 & 205 & vist \\
\hline & 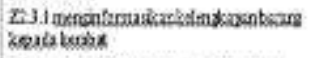 & $t .732$ & 0.301 & 205 & vas \\
\hline & 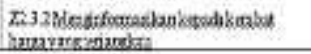 & (6) & 0า1101 & 805 & Viat \\
\hline
\end{tabular}

Sumber data diolah tahun 2016

\section{Reliabilitas}

Reliabilitas suatu pengukur menunjukkan stabilitas dan konsistensi dari suatu instrumen yang mengukur suatu konsep dan berguna untuk mengakses "kebaikan" dari suatu pengukur (Sekaran dalam Jogiyanto, 2007).

Tabel 6 Hasil Uji Reliabilitas

\begin{tabular}{|c|c|c|c|}
\hline yomited & 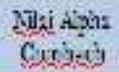 & 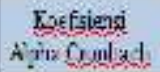 & Kescertes:- \\
\hline 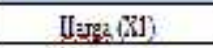 & 0.893 & 0.6 & Bejale \\
\hline Kexcharcisirg $\mathrm{X}$ ') & $0.55 C$ & 0.6 & Rfinglis \\
\hline Kazdesag (O) & Q. 730 & 0.6 & KGat \\
\hline Issins Pejanas: (I) & 0.782 & 0.6 & Reiak길 \\
\hline
\end{tabular}

Sumber data diolah tahun 2016

Hasil penelitian menunjukkan bahwa semua instrument penelitian yang digunakan adalah reliable, karena nilai alpha dari semua instrument penelitian yang digunakan mempunyai nilai yang lebih besar dari 0.6 $(\alpha=0.6)$.

\section{Metode Analisis Data}

Adapun teknik análisis data yang digunakan dalam penelitian ini adalah menggunakan statistik deskriptif dan statisitk inferensial, dengan menggunakan SPSS 22.00.

Menurut Jogiyanto (2007), statistik deskriptif merupakan statistik yang menggambarkan fenomena atau karakteristik dari data. Karakteristik data yang digambarkan adalah karakteristik distribusinya. Statistik ini menyediakan nilai frekuensi, pengukur tendensi pusat. Statistik dalam penelitian ini akan 
digunakan untuk memperlihatkan karakteristik pelanggan Minimarket Puri.

Menurut Ma'ruf (2015: 293), statistika inferensial adalah statistika yang berkenan dengan cara penarikan kesimpulan berdasarkan data yang diperoleh dari sampel untuk menggambarkan karakteristik atau ciri dari suatu populasi. Tahap statistik infrensial adalah pertama melakukan uji asumsi klasik dan yang kedua adalah uji Analisis jalur

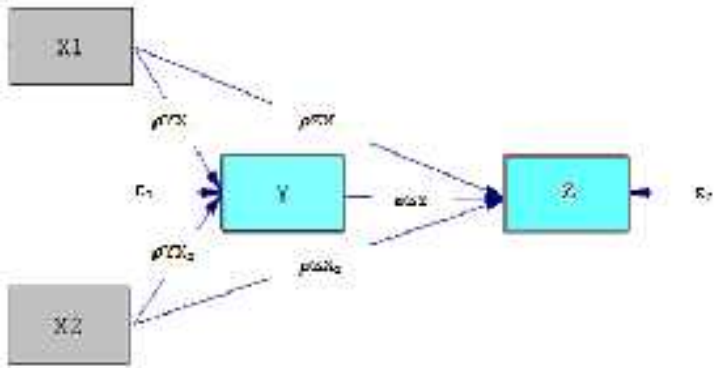

Gambar 1 Model Analisis Jalur

$$
\begin{aligned}
& \mathrm{Y}=P_{1} \cdot X_{1} \mathrm{Y}+P_{2} \cdot X_{2} \mathrm{Y}+\varepsilon_{1} \\
& \mathrm{Z}=P_{1} \cdot X_{1} \mathrm{Z}+P_{2} \cdot X_{2} \mathrm{Z}+P_{y} \cdot \mathrm{y} \mathrm{Z}+\varepsilon_{2}
\end{aligned}
$$

Menghitung kesalahan path secara langsung

Untuk satu jalur digunakan perhitungan regresi variabel yang dibakukan secara parsial pada masing-masing persamaan, maka dari perhitungan ini diperoleh path secara langsung. Sedangkan untuk pengaruh kesalahan penggangu ditentukan dengan rumus sebagai berikut:

$$
\left.\left.\sqrt{\left(1-K_{1}\right.} 2\right) \times P_{E 2}=\sqrt{\left(1-K_{2}\right.} 2\right)
$$

Mencari pengaruh tidak langsung

PTL1 $=P_{1} \mathrm{Y} \times \mathrm{PYZ}$

PTL2 $=P_{2} \mathrm{Y} \times \mathrm{PYZ}$

Artinya, pengaruh tidak langsung harga dan merchandising terhadap loyalitas pelanggan melalui kepuasan pelanggan.

\section{Pengujian Hipotesis}

Analisis ini digunakan untuk mengetahui ada pengaruh variabel independen terhadap variabel dependen secara parsial atau per variabel, dengan rumus (Irfany, 2009)
1. Uji t mempunyai kriteria apabila $t_{h u}$ $>t_{t_{1}}$ maka H0 ditolak dan dengan demikian variabel bebas dapat menerangkan variabel terikatnya dan sebaliknya.

2. Uji F dilakukan untuk mengetahui apakah semua variabel bebas mempunyai pengaruh yang sama terhadap variabel terikat. Uji F ini juga sering disebut sebagai uji simultan, apabila $\mathrm{F}_{\text {hitung }}>\mathrm{F}_{\text {tabel }}$ maka $\mathrm{H} 0$ diterima sehingga dapat dikatakan bahwa variabel bebas dari regresi dapat menerangkan variabel terikat secara serentak dan sebaliknya.

\section{HASIL DAN PEMBAHASAN}

\section{Usia}

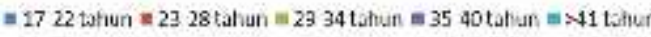

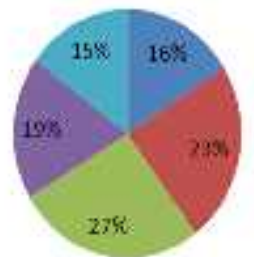

Gambar 2 Kareteristik Usia

Hasil menunjukkan bahwa dari 161 responden berusia berusia 29-34 tahun memiliki presentase sebanyak $27 \%$, responden berusia 35 40 tahun memiliki presentase sebanyak 19\%, responden berusia di atas 41 tahun memiliki presentase sebanyak $15 \%$. Berdasarkan data tersebut, dijelaskan bahwa usia pelanggan Minimarket Puri rata-rata adalah usia produktif dan wanita yang sudah berumah tangga. Wanita yang berusia produktif rata-rata tinggal di sekitar Minimarket Puri. Wanita yang berusia produktif juga tinggal berdekatan dengan Mnimarket Puri, sehingga memudahkan untuk berbelanja kebutuhan pribadi dan kebutuhan keluarga sehari-hari 


\section{Status Bekerja}

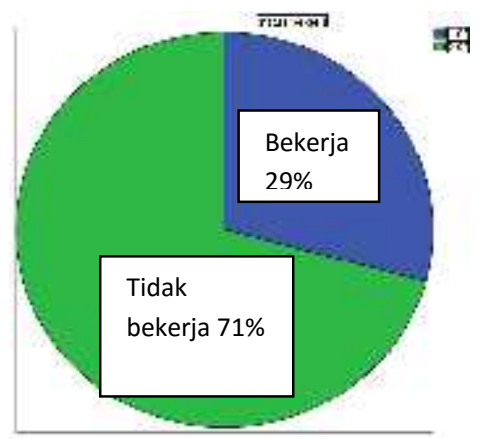

Gambar 3 Status Bekerja

Hasil penelitian menunjukkan bahwa dari 161 responden yang sudah bekerja memiliki presentase sebesar 29\%, dan yang tidak bekerja sebesar $71 \%$. Rata-rata pelanggan yang belanja di Minimarket Puri adalah wanita yang tidak bekerja atau sebagai ibu rumah tangga yang tidak memiliki pendapatan sendiri melainkan pendapatan yang diperoleh dari suami.

\section{Frekuensi Belanja Perminggu}

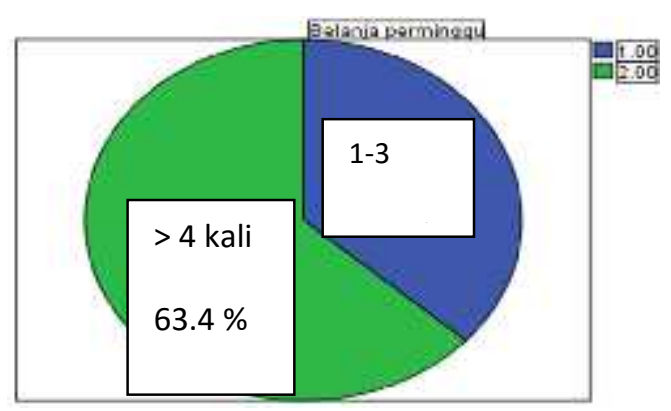

Gambar 3 Kareteristik Usia

Hasil Penelitian menunjukkan bahwa dari 161 reponden, pelanggan yang 1-3 kali frekuensi belanja dalam seminggunya memiliki presentase sebesar $36.6 \%$, dan pelanggan yang frekuensi belanja dalam seminggunya lebih dari 4 kali memiliki presentase sebesar $63.4 \%$. Dapat dijelaskan bahwa barang-barang yang dijual di Minimarket Puri sesuai dengan kebutuhan pelanggan, sehingga menarik pelanggan untuk lebih sering berbelanja. Minimarket Puri menyediakan kebutuhan pelanggan seperti sembilan kebutuhan bahan pakok (Sembako) dan kebutuhan rumah tangga serta kebutuhan pribadi.

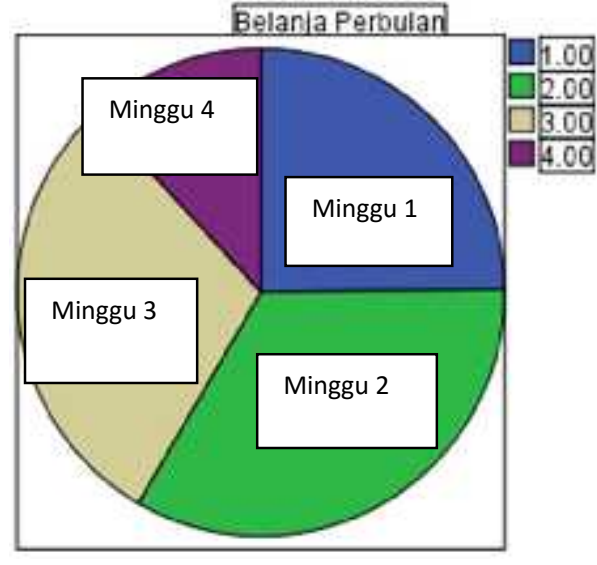

Gambar 3 Frekuensi Belanja Perbulan

Hasil penelitian menunjukkan bahwa dari 161 responden, pelanggan belanja dalam satu bulan pada minggu ke-1 sebanyak $25 \%$, pada minggu ke-2 sebanyak 33\%, pada minggu ke-3 sebanyak $30 \%$, dan pada minggu ke-4 sebanyak $12 \%$. Berdasarkan data tersebut menjelaskan bahwa pelanggan Minimarket Puri rata-rata belanja pada minggu ke-2 dan minggu ke-3. Hal ini berarti pelanggan mendapatkan uang gaji atau uang bulanan dari suami pada minggu ke-2 dan 3, kemudian mengingat letak Minimarket Puri di dalam perumahan, terdapat macammacam pekerjaan yang dimiliki pelanggan atau suami pelanggan dan memperoleh gaji di waktu yang berbeda-beda, sehingga tidak berpengaruh gajian terhadap waktu belanja di setiap bulannya.

\section{Kategori Barang yang Dibeli}

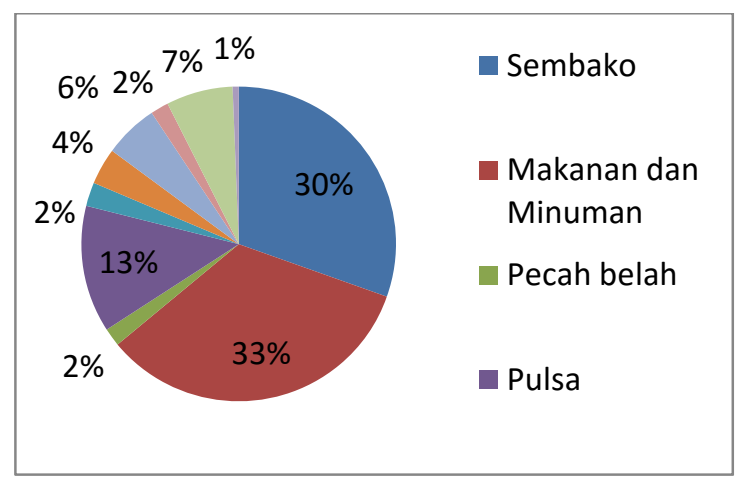

Gambar 4 Kategori Barang yang dibeli

Hasil penelitian menunjukkan bahwa dari 161 responden terlihat bahwa pelanggan yang sering membeli barang-barang kebutuhan sembako, pelanggan yang sering membeli 
makanan dan minuman seperti snack, kue/roti, minuman berasa, air putih, permen.

Ada juga pelanggan wanita yang membeli peralatan pecah belah dan pelanggan yang sering membeli pulsa. Selain membeli sembako dan barang pecah belah serta makanan dan minuman pelanggan Minimarket Puri sering membeli kosmetik, membeli sabun, sampo, pasta gigi, dan bumbu masak serta kebutuhan dapur lainnya. Pelanggan yang mempunyai anak balita sering membeli keperluan bayi seperti pampers dan susu bayi. Pelanggan Wanita Minimarket Puri juga sering membeli kebutuhan wanita.

Bisa disimpulkan bahwa pelanggan wanita yang belanja di Minimarket Puri cenderung memiliki kebutuhan sehari-hari untuk untuk individu dirinya sendiri dan keluarga.

\section{Deskripsi Variabel Harga (X1)}

Tabel 7 Deskripsi Variabel Harga (X1)

\begin{tabular}{|c|c|c|c|c|c|c|c|c|c|c|c|}
\hline \multirow{3}{*}{ fen } & \multicolumn{10}{|c|}{ Sker Jastos } & \multirow[t]{2}{*}{ Nesen } \\
\hline & \multicolumn{2}{|c|}{1} & \multicolumn{2}{|c|}{2} & \multicolumn{2}{|c|}{3} & \multicolumn{2}{|r|}{4} & \multicolumn{2}{|r|}{5} & \\
\hline & 5 & $\%$ & $F$ & $\%$ & $F$ & $\%$ & s. & $\%$ & f & $\%$ & \\
\hline 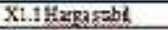 & 1 & 0.6 & 0 & 0 & 23 & 123 & 105 & 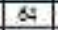 & 34 & 21.1 & 404 \\
\hline 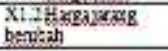 & 0 & 0 & 2 & 1.2 & 31 & 193 & 91 & 56.5 & 3) & 23 & 402 \\
\hline Xl.3 Frreassots & 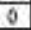 & 0 & 1 & 0.6 & 34 & 21.1 & 85 & 547 & 38 & 23.6 & 4.03 \\
\hline 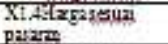 & 0 & 0 & 1 & 0.6 & 39 & 242 & 83 & 51.6 & 38 & 23.6 & 3.98 \\
\hline $\begin{array}{l}\mathrm{X} \text { X.Sprages } \\
\text { trizmaler }\end{array}$ & 0 & 0 & 1 & 0.6 & 27 & $\lfloor 6.9$ & 95 & 59.6 & 37 & 23 & 404 \\
\hline $\mathrm{X}:$ GFrabanion: & 0 & 0 & 3 & 1.9 & 34 & 211 & D5 & 55.9 & 34 & 21.1 & 3.95 \\
\hline 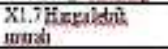 & 1 & 0.6 & 2 & 1.2 & 42 & 243 & 95 & 59,6 & 22 & 13.7 & 3.84 \\
\hline $\mathrm{XI}, \mathrm{SH}$ Heqearenos & 0 & 0 & 1 & 0.6 & 75 & 472 & 70 & 455 & 14 & 8.1 & 3.5 \\
\hline 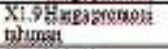 & 0 & 0 & 5 & 3.1. & 35. & 547 & 55 & $3+8$ & 12 & 2,5 & 3 is \\
\hline 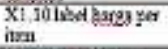 & 1 & 6.6 & 4 & 2.5 & 9y & $\infty 02$ & $5 s$ & 348 & 3 & ts & 3.34 \\
\hline $\begin{array}{l}\text { XI.MLabel bapa } \\
\text { perpiset }\end{array}$ & 0 & 0 & 2 & 13 & 33 & 49.7 & 73 & 45.3 & 6 & 3.5 & $35 !$ \\
\hline $\begin{array}{l}\text { X1.12 Labd bara in } \\
\text { nas }\end{array}$ & 1 & 0.6 & $t$ & 0,5 & 103 & 64 & ss & 28.5 & 10 & 6.2 & 339 \\
\hline 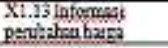 & 0 & $a$ & 1 & 0.6 & 65 & 40.4 & $\$$ & 55.3 & 6 & 3.3 & 3.62 \\
\hline 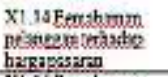 & 0 & a & 1 & 0.6 & 33 & 23 & 110 & 68.3 & 13 & 8.1 & 3.83 \\
\hline 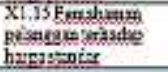 & 0 & 0 & 0 & 0 & 15 & 9.9 & 122 & $\mid 75.8$ & 23 & 14.3 & t.04 \\
\hline
\end{tabular}

Sumber data diolah tahun 2016

Tanggapan responden menunjukkan bahwa bahwa pelanggan beranggapan harga yang ditawarkan di Minimarket Puri stabil mengikuti harga pasaran, harga yang ditawarkan di Minimarket Puri jarang terjadi perubahan yang signifikan atau melakukan perubahan harga secara sepihak, harga yang ditawarkan di Minimarket Puri standar sesuai dengan harga yang telah ditetapkan dipasar, harga yang ditawarkan di Minimarket Puri sesuai dengan harga pasaran pada umumnya, harga di Minimarket Puri terjangkau dan tidak mahal, harga yang ditawarkan di Minimarket Puri dapat bersaing dengan minimarket lain, harga yang ditawarkan di Minimarket Puri lebih murah dibandingkan dengan minimarket lain, Minimarket Puri juga sering memberikan dan mengadakan harga promosi yang menarik, harga promosi yang menarik diadakan setiap tahunnya sehingga pelanggan tertarik untuk berbelanja.

Minimarket Puri memberikan label harga pada setiap barang yang dijual, namun dapat dilihat juga dari hasil presentase dan frekuensi pada skor "cukup" (ragu-ragu) cukup banyak responden yang memberikan jawaban cukup, hal itu menunjukkan masih terdapat beberapa responden yang kurang mengetahui dan tidak memperhatikan langsung label pada barang atau rak barang yang telah dipajang di Minimarket Puri. Hal tersebut disebabkan karena banyak responden yang telah mengetahui harga barang yang akan mereka beli, pada umumnya mereka telah percaya terhadap harga yang ditetapkan Minimarket Puri. Hal tersebut juga disebabkan posisi Minimarket Puri yang terletak di dalam Perumahan Puri Legenda di mana Minimarket Puri berada. Pelanggan tidak perlu repot-repot untuk mencari label harga ketika membeli barang dagangan yang dibutuhkan karena Mnimarket Puri selalu memperbaharui label harga bila ada perubahan harga.

Minimarket Puri kemudian memberikan informasi perubahan harga barang yang dijual, perubahan tersebut diinformasikan melalui label harga yang di berikan pada masing-masing item barang yang dipajang. 


\section{Deskripsi Variabel Merchandising}

Tabel 8 Deskripsi Variabel Merchandising

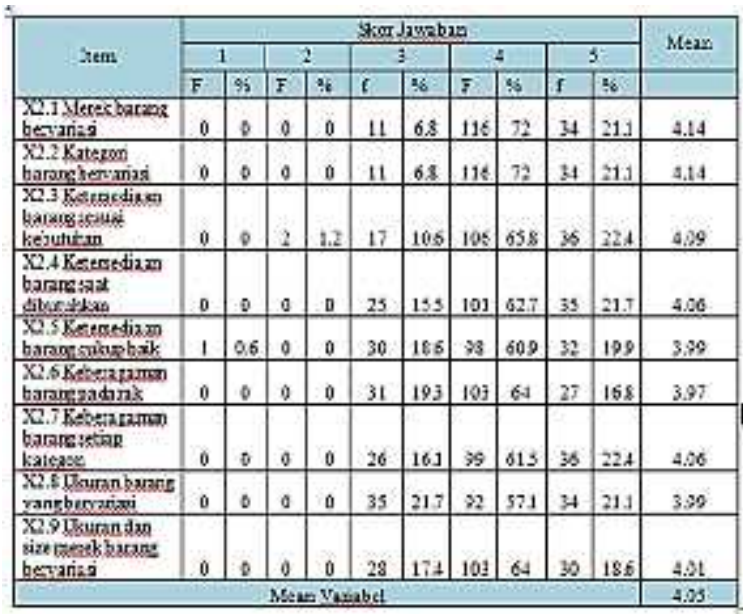

Sumber data diolah tahun 2016

Hasil penelitian menunjukkan bahwa pelanggan merasa puas dengan keberagaman dan ketersediaan barang dagangan serta harga yang ada di Minimarket Puri.Terdapat satu orang menjawab sangat tidak setuju dengan harga yang ditetapkan di Miniarket Puri hal tersebut bisa disebabkan karena pelanggan tersebut merupakan pelanggan pendatang baru yang belum mengetahui secara keseluruhan harga barang di Minimarket Puri dan secara kebetulan barang yang dibeli sedang mengalami kenaikan atau harga barang yang dibeli adalah harga barang yang belum stabil sepeeti harga sembako.

Pelanggan merasa puas karena Minimarket Puri menjual barang kebutuhan pokok dan juga kebutuhan sampingan lainnya, sehingga pelanggan mudah untuk mendapatkan barang yang mereka butuhkan. Pelanggan juga merasa puas dengan keberagaman barang yang dijual selain itu harga yang ditetapkan juga standar, sehingga pelanggan menjadi puas dan nyaman untuk belanja di Minimarket Puri.

\section{Deskripsi Variabel Loyalitas Pelanggan}

Tabel 9 Deskripsi Variabel Loyalitas Pelanggan

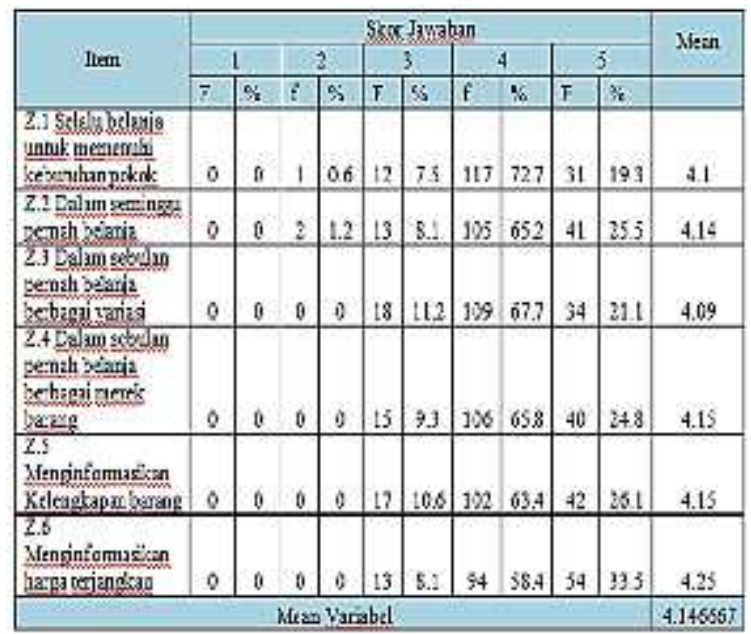

Sumber data diolah tahun 2016

Hasil penelitian menujukkan bahwa pelanggan sekitar selalu belanja untuk memenuhi kebutuhan pokok dan kebutuhan sehari-harinya di Minimarket Puri, dalam waktu satu minggu dan satu bulan pelanggan yang tinggal di Puri Legenda pernah berbelanja di Minimarket Puri. Dalam waktu satu bulan pelanggan yang tinggal di Puri Legenda pernah berbelanja berbagai variasi merek barang dagangan di Minimarket Puri.

Responden menganggap merek yang dijual di Minimarket Puri lengkap sehingga mereka selalu berulang-ulang dalam membeli barang kebutuhan. Pelanggan juga menginformasikan atau memberitahu kepada kerabat atau orang lain bahwa barang yang dijual di Minimarket Puri lengkap dan menawarkan harga yang terjangkau. Dengan demikian pelanggan akan merekomendasikan orang lain untuk belanja di Minimarket Puri.

\section{Asumsi Klasik}

\section{Hasil Uji Normalitas Data}

Hasil uji normalitas dengan menggunakan menggunakan metode Kolmogorov-Smirnov dengan kriteria pengujian apabila nilai Sig yang diperoleh lebih besar dari 0,05, dapat disimpulkan jika data yang digunakan 
berdistribusi normal. Berikut diperoleh hasil sebagai berikut:

Tabel 10 Uji Normalitas Data

\begin{tabular}{|c|c|c|c|c|c|}
\hline & & $\begin{array}{l}\text { Hegs } \\
\text { (XI) }\end{array}$ & $\begin{array}{c}\text { Merchantistag } \\
(\mathrm{xz})\end{array}$ & $\begin{array}{c}\text { Repuzsun } \\
\text { Pelangan (X) }\end{array}$ & $\begin{array}{c}\text { Loyatitas } \\
\text { Petangan (Z) }\end{array}$ \\
\hline $\mathrm{N}$ & & 161 & 161 & 161 & 161 \\
\hline Nomral & Mean & 56,9066 & 36,4783 & 16,1491 & $24,9: 93$ \\
\hline Parameces" & Std Deviation & 6,19093 & 3,64515 & $1,8241 \mathrm{~s}$ & 2,38478 \\
\hline Mrstextreme & Absolute & 0,111 & 0,161 & 0,135 & 0,68 \\
\hline \multirow[t]{2}{*}{ Diffeserces } & Positive & 0,111 & 0,161 & 0,185 & 0,68 \\
\hline & Nepgative & 0,084 & 0,074 & $-0,132$ & 0,100 \\
\hline \multicolumn{2}{|c|}{ Kòmpgotov-Strimov $Z$} & 1,312 & 1,041 & 1,344 & 1,201 \\
\hline \multicolumn{2}{|c|}{ Asymip. Siz (2-taled) } & 0,057 & 0,148 & 0,051 & 0,29 \\
\hline
\end{tabular}

Sumber data diolah tahun 2016

\section{Hasil Uji Multikolinieritas}

Hasil uji Multikolinieritas bertujuan untuk melihat apakah model regresi ditemukan adanya korelasi yang tinggi atau sempurna antar variabel independen. Multikolinieritas dapat dilihat dari nilai tolerance dan lawannya variance inflation factor (VIF). Nilai cutoff yang umum dipakai untuk menunjukkan adanya multikolinieritas adalah tolerance $<0.10$ atau sama dan VIF > 10, bisa diartikan bahwa bila VIF lebih kecil dari 10 dan nilai tolerance tidak lebih kecil dari 0.10 maka tidak terjadi multikolinieritas. Hasil uji multikolinieritas dapat dillihat pada tabel:

Tabel 11 Uji Multikolinieritas Pertama

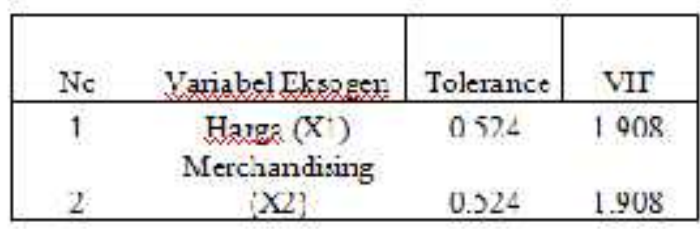

Sumber data diolah tahun 2016

Tabel 12 Uji Multikolinieritas Kedua

\begin{tabular}{|c|c|c|c|}
\hline No & Varabel Ehsuxat & Tules $20 x=$ & VIF \\
\hline+ & $\begin{array}{c}\text { Jarge (XI) } \\
\text { Therchandsing }\end{array}$ & $0>79$ & 1776 \\
\hline 2 & $(x)$ & 0.517 & 1934 \\
\hline ; & 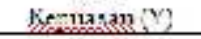 & $05 \times 6$ & $1+23$ \\
\hline
\end{tabular}

Sumber data diolah tahun 2016

Berdasarkan tabel di atas tidak ada variabel independen yang memiliki nilai tolerance yang kurang dari 0.10 dan VIF lebih keci dari 10. Maka, tidak ada multikolinieritas antar variabel independen dalam model persamaan pertama dan kedua, sehingga hasil dari olah data dapat digunakan sebagai suatu persamaan regresi.

\section{Analisis Jalur}

Analisis jalur digunakan untuk menaksir hubungan jalur kausalitas antara variabel yang telah ditetapkan berdasarkan teori. Terdapat 2 model jalur yaitu satu persamaan jalur dan model dua persamaan jalur

Tabel 13 Hasil Koefesien Analisis Jalur Pertama

\begin{tabular}{|c|c|c|c|c|c|}
\hline Variabel Eudugea & 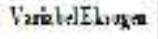 & $B: 12$ & I & Si & Kelemangen \\
\hline \multirow{2}{*}{ 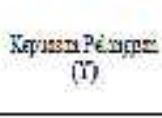 } & Herngil & 6474 & 3.100 & $0.00\rangle$ & 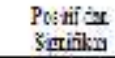 \\
\hline & 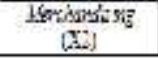 & 0.413 & $706 \%$ & 0.002 & $\begin{array}{l}\text { Potificin } \\
\text { Sinifikv }\end{array}$ \\
\hline R & \multicolumn{3}{|l|}{$-(1.134$} & $\begin{array}{l}\text { Kari } \\
\text { Kntt: }\end{array}$ & \\
\hline RSqur? & \multicolumn{3}{|l|}{$=0.533$} & trited & $=1.97:$ \\
\hline 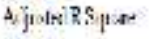 & \multirow{2}{*}{\multicolumn{3}{|c|}{ 110 ${ }^{-65 \%}$}} & F div & -3053 \\
\hline thrme & & & & & \\
\hline
\end{tabular}

Sumber data diolah tahun 2016

$$
\mathrm{Y}=0.4 \quad X_{1}+0.4 \quad X_{2}+0.4
$$

Pada tabel di atas, menjelaskan bahwa hasil pengujian secara simultan dan parsial pengaruh variabel eksogen Harga dan Merchandising terhadap Kepuasan Pelanggan. Pada uji F dengan tingkat signifikansi 0.000 , diperoleh nilai $\mathrm{F}$ hitung $=110.592$ dan $\mathrm{F}$ tabel $=3.053$, maka terbukti bahwa nilai $\mathrm{F}$ hitung lebih besar dari $\mathrm{F}$ tabel, dan $\mathrm{t}$ hitung pada variabel harga sebesar $=$ 8.100 lebih besar dari t tabel $=1.975$ dan variabel Merchandising t hitung $=7.065$ lebih besar dari $\mathrm{t}$ tabel $=1.975$, itu berarti terdapat pengaruh secara parsial dan simultan antar variabel.

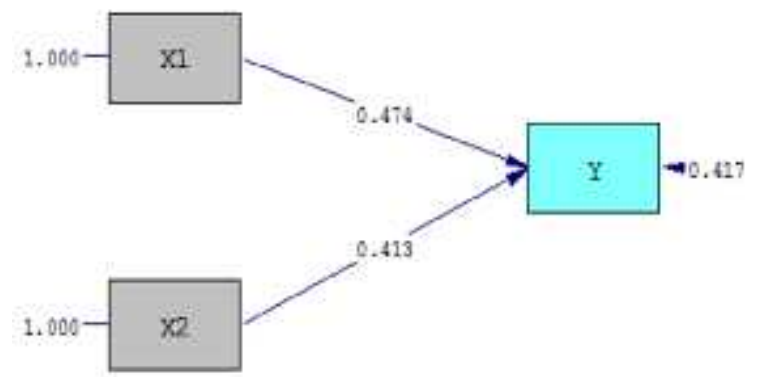

Gambar 2 Model Analisis Jalur Pertama 
Tabel 14 Hasil Analisis Jalur Kedua

\begin{tabular}{|c|c|c|c|c|c|}
\hline $\begin{array}{l}\text { Tariabel } \\
\text { Eadogen }\end{array}$ & Variabel Eksoggen & Beta & $\mathrm{T}$ & Sig & Keterangan \\
\hline \multirow{3}{*}{$\begin{array}{c}\text { Loyaltas } \\
\text { Pelangen (C) }\end{array}$} & Harza (XI) & 0.260 & 3.355 & 0.001 & $\begin{array}{c}\text { Ididak } \\
\text { Sigyifikan }\end{array}$ \\
\hline & $\begin{array}{l}\text { Merchardising } \\
\left(x_{2}\right)\end{array}$ & 0.295 & 3945 & 0,000 & $\begin{array}{l}\text { Postaf dan } \\
\text { Sigiflkan }\end{array}$ \\
\hline & Keguasan (Y) & 0263 & 2.973 & 0,003 & $\begin{array}{l}\text { Positif dan } \\
\text { Sigufikan }\end{array}$ \\
\hline 3 & \multicolumn{3}{|l|}{0.698} & $\begin{array}{l}\text { Nìzi } \\
\text { Krits } \\
\text { t }\end{array}$ & \multirow{3}{*}{1975} \\
\hline $\begin{array}{l}\text { R Square } \\
\text { Adjusted R }\end{array}$ & \multicolumn{3}{|l|}{0.488} & $\begin{array}{l}\text { tabel } \\
F\end{array}$ & \\
\hline $\begin{array}{l}\text { Square } \\
\text { FHotimg }\end{array}$ & $\begin{array}{r}0.478 \\
49.854\end{array}$ & & & table & \\
\hline
\end{tabular}

$\mathrm{Z}=0.260 X_{1}+0.2 X_{2}+0.263 \mathrm{Y}+$ $0.5 \quad \ldots . .(2)$

Pada tabel di atas, menjelaskan bahwa hasil pengujian secara simultan dan parsial pengaruh variabel eksogen Harga Merchandising dan Kepuasan terhadap Loyalitas Pelanggan. Pada uji $\mathrm{F}$ dengan tingkat signifikansi 0.000, diperoleh nilai $\mathrm{F}$ hitung $=49.854$ dan $\mathrm{F}$ tabel $=$ 2.66, maka terbukti bahwa nilai $\mathrm{F}$ hitung lebih besar dari $\mathrm{F}$ tabel, dan $\mathrm{t}$ hitung pada variabel harga sebesar $=3.355$ lebih besar dari $\mathrm{t}$ tabel $=$ 1.975 dan variabel Merchandising t hitung = 3.945 lebih besar dari $t$ tabel $=1.975$, itu berarti terdapat pengaruh secara parsial dan simultan antar variabel.

Sehingga terbentuk persamaan kedua análisis jalur pertama dan kedua sebagai berikut:

$Y=0,474 X_{1}+0,413 X_{2}+0,417\left(\varepsilon_{1}\right)$

$Z=0,260 X_{1}+0,295 X_{2}+0,263 X_{3}+0,512$

$\left(\varepsilon_{1}\right)$

Jika disajikan kedalam bentuk model jalur, nilai korelasi (r), koefisien jalur $(\rho)$ serta epsilon $(\varepsilon)$ akan tampak sebagai berikut:

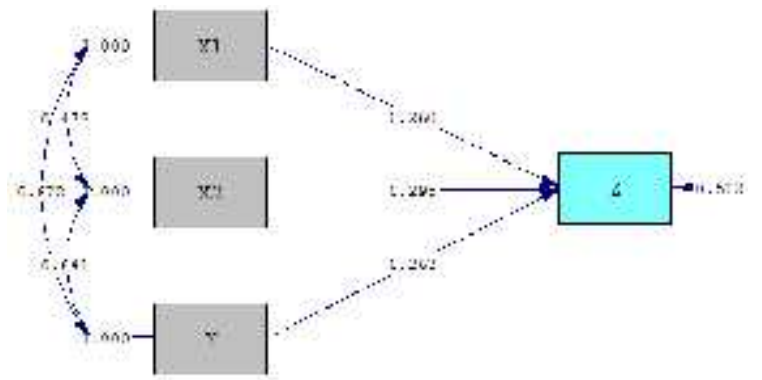

\section{Pengaruh Variabel Harga (X1) terhadap Kepuasan Pelanggan (Y)}

Berdasarkan analisis statistik inferensial dengan analisis jalur, terbukti bahwa pengujian hipotesis 1 diterima dan berdasarkan statistik deskriptif mean variabel Harga berada pada daerah tengah-tengah dan cukup baik, dengan nilai mean sebesar 3.77. Hasil sig yang ditunjukkan dengan nilai beta sebesar $0.474, \mathrm{t}$ hitung hasil koefisien jalur pertama sebesar 8.100 dan tingkat signifikansi 0.000 dibawah 0.05 . bisa dikatakan ada pengaruh yang signifikan antara Harga terhadap Kepuasan Pelanggan.

Harga yang ditawarkan Minimarket Puri kepada pelanggan cukup memuaskan. Pada dasarnya, harga merupakan penentu bagaimana pelanggan akan puas atau tidak terhadap suatu produk, harga yang sesuai pada kualitas produk akan menimbulkan efek yang baik dan rasa puas, namun harga yang tidak sesuai akan menimbulkan rasa jera kepada pelanggan terhadap suatu produk tersebut.

Hasil penelitian ini sejalan dengan hasil penelitian Wahono dan Subagio (2013), yang menyebutkan harga merupakan faktor dominan yang mempengaruhi kepuasan pelanggan. Sejalan juga dengan penelitian yang dilakukan Indah (2012), menyimpulkan bahwa mayoritas responden menyatakan dengan harga yang murah pelanggan akan merasa puas, Sehingga pengaruh harga terhadap kepuasan pelanggan sangat kuat. Kemudian ssejalan dengan penelitian yang dilakukan oleh Widoretno (2013), mengungkapkan bahwa harga menunjukkan adanya pengaruh positif semakin tinggi harga yang dipersepsikan maka tingkat kepuasan palanggan juga semakin kuat. Sebaliknya, jika persepsinya terhadap harga semakin rendah maka tingkat kepuasan pelanggan juga semakin rendah.

Gambar 3 Model Jalur Kedua 


\section{Pengaruh Merchandising Kepuasan Pelanggan (Y)}

(X2) terhadap

Berdasarkan analisis statistik inferensial dengan analisis jalur, terbukti bahwa pengujian hipotesis 2 diterima dan berdasarkan statistik deskriptif mean variabel Merchandising berada pada daerah yang baik, dengan nilai mean sebesar 4.06. Hasil sig yang ditunjukkan dengan nilai beta sebesar 0.413 , t hitung hasil koefisien jalur pertama sebesar 7.065 dan tingkat signifikansi 0.000 dibawah 0.05 . bisa dikatakan ada pengaruh yang signifikan antara Merchandising terhadap Kepuasan Pelanggan.

Hasil tanggapan dari responden terhadap kuesioner yang disebar terbukti responden puas terhadap barang dagangan yang dijual di Minimarket Puri, karena tidak hanya barang yang dijual bervariasi, pengelolaan barang juga cukup baik, sehingga pelanggan mudah mendapatkan barang sesuai dengan keinginan dan tidak perlu jauh-jauh mencari tempat lain untuk berbelanja.

Penelitian ini sejalan dengan penelitian terdahulu yang dilakukan Vincentius dan Wulandari (2015), menyatakan bahwa variabel Merchandise berpengaruh positif dan signifikan terhadap variabel Kepuasan Pelanggan dimana kelengkapan barang dan kualitas Merchandise akan meningkatkan kepuasan pelanggan. Sejalan dengan Utami (2010), didalam bukunya menuliskan keberagaman dan variasi barang dagangan merupakan daya tarik tersendiri bagi sebuah ritel dan merupakan hal penting bagi pelanggan. Kemampuan untuk mengelola pilihan terhadap keberagaman barang dagangan tersebut juga menjadi faktor yang sangat penting bagi ritel. Artinya jangan sampai ritel menyiapkan variasi barang dagangan dengan sifat yang slow moving (lamban penjualannya) terlalu banyak sehingga membebani biaya persediaan.

\section{Pengaruh Harga (X1) terhadap Loyalitas Pelanggan (Z)}

Berdasarkan analisis statistik inferensial dengan analisis jalur, terbukti bahwa pengujian hipotesis 3 diterima dan berdasarkan statistik deskriptif mean variabel Harga berada pada daerah yang baik dan sangat positif, dengan nilai mean sebesar 3.77. Hasil yang ditunjukkan dengan nilai beta sebesar 0.260 , t hitung hasil koefisien jalur kedua sebesar 3.355 dan tingkat signifikansi 0.001 dibawah 0.05 . bisa dikatakan ada pengaruh yang signifikan antara Harga terhadap Loyalitas Pelanggan.

Pelanggan akan semakin loyal apabila penerimaan harga yang baik, hal tersebut akan menimbulkan persepsi yang positif terhadap toko di mana, pelanggan merasa harga yang diberikan cukup, sehingga pelanggan akan merasa puas dan menimbulkan sikap loyal. Melalui variabel harga para pebisnis ritel dapat mengambil peluang dalam menarik hati pelanggan. Pengelolaan harga yang baik meliputi, pemberian harga yang sesuai dengan kualitas barang dagangan, pemberian harga sesuai dengan harga pasaran, informasi harga yang baik dan jelas.

Penelitian ini sejalan dengan penelitian yang dilakukan oleh Widoretno (2013), menyatakan variabel harga menunjukkan adanya pengaruh positif semakin tinggi harga yang dipersepesikan maka tingkat kepuasan pelanggan juga semakin kuat. Sebaliknya, jika persepsinya terhadap harga semakin rendah maka tingkat kepuasan pelanggan juga semakin rendah. Melalui variabel kepuasan pelanggan, semakin tinggi persepsi variabel harga maka secara langsung akan meningkatkan loyalitas pelanggan. Sejalan juga dengan penelitian yang dilakukan Kurniasih (2012), menyatakan harga berpengaruh secara signifikan terhadap kepuasan pelanggan sehinggan menimbulkan loyalitas pelanggan. 


\section{Pengaruh Merchandising (X2) terhadap Loyalitas Pelanggan (Z)}

Berdasarkan analisis statistik inferensial dengan analisis jalur, terbukti bahwa pengujian hipotesis 4 diterima dan berdasarkan statistik deskriptif mean variabel Merchandising berada pada daerah yang baik dan sangat positif, dengan nilai mean sebesar 4.06. Hasil sig yang ditunjukkan dengan nilai beta sebesar 0.295 , $\mathrm{t}$ hitung hasil koefisien jalur kedua sebesar 3.945 dan tingkat signifikansi 0.000 dibawah 0.05 . bisa dikatakan ada pengaruh yang signifikan antara Merchandising terhadap Loyalitas Pelanggan.

Merchandising (pengelolaan barang dagangan) yang diberikan Minimarket Puri kepada pelanggan cukup baik seperti kelengkapan kategori dan merek barang yang dijual, pengelolaan pajangan barang yang dijual, dan ketersediaan barang yang cukup, mampu memberikan rasa puas terhadap pelanggan sehingga pelanggan akan datang untuk belanja lagi.

Hal ini berarti telah tercipta rasa loyal pelanggan terhadap Minimarket Puri melalui produk yang dijual. Pelanggan akan melakukan pembelian ulang yang dilakukan secara terusmenerus, apalagi letak Minimarket Puri yang berada didalam perumahan masyarakat sekitar akan menganggap mereka tidak perlu jauh-jauh untuk mencari produk yang mereka butuhkan apabila Minimarket Puri sudah dapat memenuhi kebutuhannya. Ini berarti variabel Merchandising memiliki pengaruh yang signifikan terhadap Loyalitas Pelanggan.

Penelitian ini sejalan dengan Utami (2010), di dalam bukutnya menyebutkan Citra sebuah toko atau ritel dapat dibangun berdasarkan karakteristik barang dagangan yang dipajang atau ditawarkan untuk dibeli pelanggan sehinggan dapat membuat pelanggan yang loyal. Kemudian sejalan dengan penelitian yang dilakukan Widoretno (2013), yang menunjukkan adanya pengaruh positif Merchandise terhadap Loyalitas Pelanggan, implementasinya adalah, semakin tinggi faktor variabel Merchandise maka tingkat kepuasan pelanggan juga semakin kuat. Melalui variabel kepuasan, semakin tinggi persepsi varibel Merchandise maka secara langsung akan meningkatkan loyalitas pelanggan.

\section{Pengaruh Kepuasan Pelanggan (Y) terhadap Loyalitas Pelanggan (Z)}

Berdasarkan analisis statistik inferensial dengan analisis jalur, terbukti bahwa pengujian hipotesis 5 diterima dan berdasarkan statistik deskriptif mean variabel Kepuasan berada pada daerah yang baik dan sangat positif, dengan nilai mean sebesar 4.25. Dapat juga dilihat dari nilai signifikan sebesar 0.003 lebih kecil dari 0.05, beta sebesar 0.263 , $t$ hitung sebesar 2.973 lebih besar dari t tabel 1.975 yang artinya kepuasan berpengaruh signifikan terhadap loyalitas pelanggan.

Seperti yang sudah dijelaskan, pelanggan yang merasa puas akan kembali membeli Iproduk tersebut, begitu pula sebaliknya, pelanggan yang tidak mendapatkan kepuasan disaat belanja tidak akan datang kembali untuk membeli sebuah produk. maka untuk menciptakan sebuah sikap loyalitas perlu ada tahap dimana tingkat kepuasan yang tinggi yang dirasakan pelanggan terhadap suatu produk atau perusahaan.

Penelitian ini sejalan dengan penelitian yang dilakukan Widoretno (2013), menyatakan bahwa variabel kepuasan berpengaruh positif dan signifikan terhadap loyalitas pelanggan, terdapat kontribusi langsung dari kepuasan terhadap loyalitas pelanggan. Sejalan juga dengan penelitian yang dilakukan oleh Indah (2012), yang menunjukkan pengaruh yang positif dan signifikan antara kepuasan terhadap loyalitas pelanggan.

Pengaruh Harga (X1), Merchandising (X2), terhadap Kepuasan Pelanggan (Y) dan Dampakanya pada Loyalitas Pelanggan $(Z)$

Berdasarkan analisis statistik inferensial dengan analisis jalur, terbukti bahwa pengujian hipotesis 6 diterima. Dalam penelitian ini 
terbukti dengan hasil $\mathrm{F}$ hitung sebesar 49.854 lebih besar dari $\mathrm{F}$ tabel 2.662. Artinya bahwa Harga dan Merchandising mempunyai pengaruh yang simultan atau secara bersama-sama terhadap kepuasan pelanggan maupun loyalitas pelanggan. Pengelolaan Harga maupun Merchandising yang baik merupakan cara perusahaan untuk meningkatkan omset penjualan. Sehingga Harga dan Merchandising memegang peran penting untuk meningkatkan kepuasan pelanggan.

Keuntungan perusahaan akan sendirinya tercapai apabila pelanggannya merasakan kepuasan dan loyal. Untuk itu, diperlukan pengelolaan yang baik dan penetapan harga yang stabil. Karena pelanggan merupakan target utama dari sebuah kegiatan ritel yang mempunyai peranan penting untuk menghasilkan pendapatan perusahaan melalui produk yang dijual.

Penelitian ini sejalan dengan penelitian yang dilakukan Santoso (2012), manyatakan bahwa bauran pemasaran termasuk harga dan merchandise secara bersama-sama berpengaruh terhadap kepuasan dan loyalitas pelanggan.

\section{SIMPULAN}

\section{Simpulan}

Berdasarkan pembahasan pada temuan hasil penelitian ini maka dapat disimpulkan beberapa hal sebagai berikut:

1) Variabel harga menunjukkan adanya pengaruh positif dan signifikan terhadap kepuasan pelanggan. Pada dasarnya, harga merupakan penentu bagaimana pelanggan akan puas atau tidak terhadap suatu produk, harga yang sesuai pada kualitas produk akan menimbulkan efek yang baik dan rasa puas, namun harga yang tidak sesuai akan menimbulkan rasa jera kepada pelanggan terhadap suatu produk tersebut. Begitu juga dengan variabel merchandising, menunjukkan adanya pengaruh positif dan signifikan terhadap kepuasan pelanggan. Merchandising (barang dagangan) merupakan faktor pendukung di mana perusahaan dapat menjalankan bisnis ritelnya. Perusahaan dapat memberi persepsi yang baik terhadap konsumen melalui barang dagangan yang ditawarkan.Pengelolaan merchandising yang baik akan menimbulkan persepsi pelanggan yang baik pula terhadap toko dan sebaliknya. Sehingga dengan persepsi yang baik hal tersebut akan memberikan rasa puas terhadap pelanggan.

2) Variabel Harga menunjukkan bahwa adanya pengaruh yang positif dan signifikan terhadap loyalitas pelanggan. Semakin tinggi tingkat kepuasan terhadap harga yang ditawarkan maka semakin tinggi pula loyalitas pelanggan. Pelanggan akan semakin loyal apabila pemberian harga terhadap suatu barang sesuai dengan kualitasnya. Harga yang ditawarkan Minimarket Puri lebih murah dibandingkan dengan minimarket lainnya sehingga mampu memberi persepsi yang baik terhadap pelanggan. Variabel merchandising berpengaruh positif dan signifikan terhadap loyalitas pelanggan. Hal itu dilihat dari rasa puas pelanggan yang cukup kuat terhadap barang yang dijual. Pengadaan barang dan pengelolaannya yang baik akan membuat pelanggan merasa mudah untuk mendapatkan atau menemukan barang yang mereka butuhkan, sehingga timbul rasa percaya untuk terus-menerus membeli barang yang mereka butuhkan di Minimarket Puri.

3) Variabel harga, merchandising dan kepuasan menunjukkan adanya pengaruh yang simultan atau secara bersama-sama terhadap loyalitas pelanggan. Secara keseluruhan harga dan merchandising di Minimarket Puri mampu memberi pengaruh yang signifikan terhadap loyalitas pelanggannya, karena adanya pengelolaan yang baik sehingga memberikan persepsi yang baik pula kepada pelanggan. 


\section{DAFTAR PUSTAKA}

Abdullah, Ma'ruf. (2015). Metodologi Penelitian Kuantitatif untuk: Ekonomi, Manajemen, Komunikasi, dan Ilmu Sosial lainnya. Sleman Yogyakarta: Aswaja Pressindo.

Barletta, Martha. (2004).Marketing to Women: Mendongkrak Laba dari Konsumen Paling Kaya dalam Segmen Pasar Terbesar. Penerbit PPM: Jakarta

Gentha Maheza, Vincentius., \& Wulandari Kusumadewi, Ni Made. (2015). Pengaruh Retail Mix terhadap Kepuasan Pelanggan pada Unagi Bali Handycraft and Souvenir Gallery di Kota Denpasar. Jurnal Manajemen Unud, 4(7), 1883-1901.

Jogiyanti. (2007). Metodologi Penelitian Bisnis: Salah Kaprah dan PengalamanPengalaman (Edisi 2007). Yogyakarta: BPFE.

Kotler, Philip., \& Keller. (2008). Manajemen Pemasaran (Edisi 13). Jakarta: Erlangga.

Mamang Sangadji, Etta., \& Sopiah. (2013). Perilaku Konsumen Pendekaatan Praktis disertai: Himpunan Jurnal Penelitian. Yogyakarta: Andi Yogyakarta.

Santoso, Alfa. (2012). Pengaruh Retail Marketing Mix terhadap Loyalitas Konsumen dengan Kepuasan. JRMB, 7(2), 97-113.

Sopiah., \& Syihabudhin. (2008). Manajemen Bisnis Ritel. Yogyakarta: Andi Yogyakarta.

Tjiptono, Fandy., \& Chandra, Gregorius. (2012). Pemasaran Strategik: Mengupas Pemasaran Strategik, Branding Strategy, Customer Satisfaction, Strategi Kompetitif, hingga e-Marketing (Edisi 2). Yogyakarta: Andi Yogyakarta.

Wahono, Erlin., \& Subagio, Hartono. (2013). Analisa Pengaruh Retail Mix terhadap Kepuasan Pelanggan di Calais Grand City Surabaya. Jurnal Manajemen Pemasaran Petra, 1(1), 1-9.

Whidya Utami, Christina. (2010). Manajemen Ritel: $\quad$ Strategi dan Implementasi Operasional Bisnis Ritel Modern di Indonesia (Edisi 2). Jakarta: Salemba Empat.

Widoretno. (2014). Analisis Pengaruh Bauran Pemasaran Ritel terhadap Kepuasan dan Loyalitas Pelanggan Berbelanja di Giant Hypermart Kota Pekanbaru. Jurnal Tepak Manajemen Bisnis, 6(2), 99-109. 